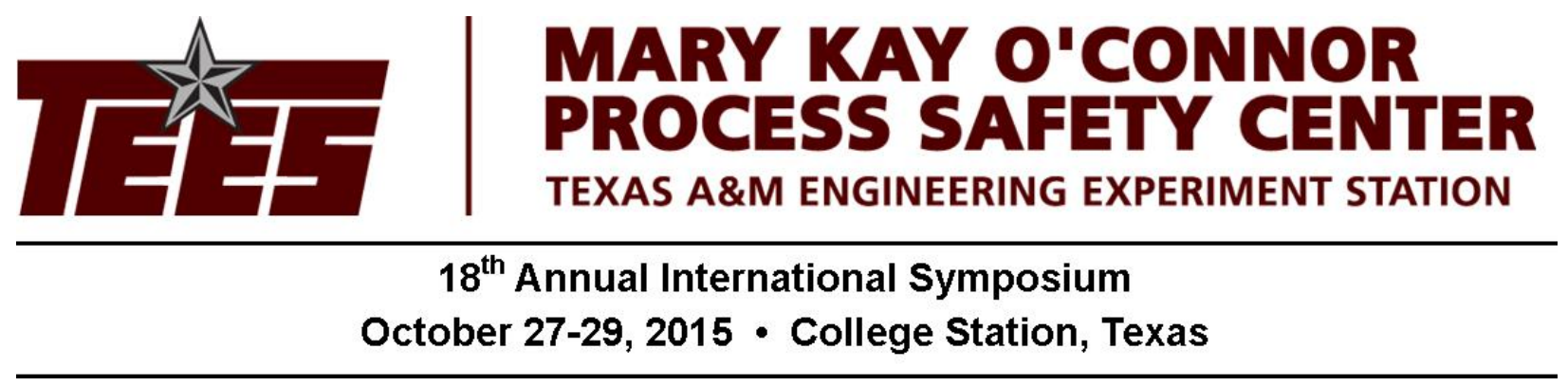

\title{
Life-Safety Concerns in Chemical Plants
}

\author{
By \\ Richard W. Prugh, NFPA Member, PE, CSP \\ Chilworth Technology, Inc., a Dekra Company \\ 113 Campus Drive, Princeton, NJ 08540
}

\begin{abstract}
$\underline{\text { Abstract }}$
The safety and health standards of the Occupational Safety and Health Act [OSHA] do not specifically address life safety in chemical plants, other than requiring owners and operators to "provide a safe place to work" and to ensure that "employees may evacuate the workplace safely”. NFPA 101 would classify chemical plants as high-hazard industrial occupancies, and a primary concern is to ensure "minimal danger to occupants in case of fire or other emergency before they have time to use exits to escape". NFPA 1 also requires that the design and operation of buildings and facilities "provide an environment for the occupants that is reasonably safe from fire and similar emergencies, for the amount of time needed to evacuate”. Thus, most life-safety requirements are concerned with safe exit.

There are, however, other life-safety hazards that should be of concern to chemical plant owners and operators. They include many single-exit locations, such as the upper levels on distillation/fractionation columns, scrubbers, and other tall equipment; elevated work platforms as atop multi-story buildings and smokestacks; platforms above tank cars, tank trucks, and hopper cars; at the head of bucket elevators; work spaces above false ceilings; and ladder-access roofs over operating areas. Also, chemical-plant life-safety hazards include flash fire [flammable vapors and combustible dusts]; releases of toxic gases and vapors; and vessel rupture from runaway reaction or other causes of overpressure. This paper presents practical countermeasures for these life-safety hazards.

\section{$\underline{\text { Introduction }}$}

The Williams-Steiger Act of 1970 [Reference 1] established the Occupational Safety and Health standards, and it included the statement that a purpose of this Act was to "provide for the general welfare, to assure so far as possible every working man and woman in the Nation safe and healthful working conditions.”
\end{abstract}


The accompanying "General Duty” clause of the Occupational Safety and Health Act [Reference 2] provides the following requirement for "life safety":

Each employer shall furnish to each of his employees .... . a place of employment which [is] free from recognized hazards that are causing or are likely to cause death or serious physical harm to his employees.

The primary source for life-safety requirements is the "Life Safety Code" of the National Fire Protection Association, as NFPA 101 [Reference 3]. The purpose of this Code is "to provide minimum requirements, with due regard to function, for the design, operation, and maintenance of buildings and structures for safety to life [emphasis added] from fire" and to "aid life safety in similar emergencies." An additional statement is that a goal of this Code is to "provide life safety during emergencies that can be mitigated using methods comparable to those used in case of fire.” Further, emergencies would include "incidents where the hazard involves thermal attributes similar to fires or airborne contaminants similar to smoke, and explosions and hazardous material releases." However, "the Code recognizes that features mandated by this Code might be less effective against such hazards than against fires.”

Thus, many of the requirements and guidance that are provided in this Code can aid in the design of chemical-plant facilities and structures. Foremost in the requirements of the Life Safety Code is assurance that occupants of a structure are to be able to exit from the structure to a safe location at ground level.

\section{OSHA Requirements}

The Safety and Health Standards of the Occupational Safety and Health Act [OSHA] address several limited [and non-quantitative] aspects of exits, as follows:

- Employers must provide exit routes so that employees may evacuate the workplace safely during an emergency [Reference 4].

- Maintenance, safeguards, and operational features for exit routes protect and minimize the danger to employees during emergency egress [Reference 5].

This "Means of Egress" section of the OSHA Standards [Reference 6] refers to the "Life Safety Code" of the National Fire Protection Association and to the International Fire Code [Reference 7]. However, the "quantitative" requirements of these Codes are not included in the OSHA Standards. Guidance concerning emergency-warning times, travel distances, travel times, and the design of escape routes are presented in the following sections, together with the justifications for rapid escape in an emergency.

\section{Types of Life-Safety Hazards in Chemical Plants}

There are wide varieties of life-safety [fatality] hazards in many chemical plants. They can include the following, in an approximate descending order of risk [Reference 8]: 
- $\quad$ Fire hazards, as exposure to thermal radiation, engulfment in flame, or inhalation of smoke or combustion gases

- $\quad$ Exposure to toxic gases or vapors, toxic or corrosive liquids, and toxic dusts

- $\quad$ Exposure to oxygen-depleted atmospheres, with risk of asphyxiation

- $\quad$ Suffocation from engulfment in powders, or drowning in liquids

- $\quad$ Explosion hazards, as exposure to blast effects, shrapnel, or structural collapse

- $\quad$ Exposure to the above hazards while entrapped in single-exit situations or circumstances

There are many types of chemical processes that can lead to one or more of the above hazards. Loss of containment of hazardous materials or loss of control of processes often can lead to release of flammable, explosible, or toxic materials. Ideally, a Process Hazards Analysis [PHA] or Risk Assessment [RA] can identify the causes of such incidents and lead to correction of the causes.

There may be other life-safety hazards and, although they are important concerns of safety and health managers, they are not within the scope of this presentation:

Industrial-type hazards of slipping, tripping, falling from elevations, and dropped loads Hazards of impact, crushing, or other trauma in powered equipment Incidents involving lift trucks, delivery and product trucks, automobiles, and other vehicles Exposures to earthquakes, landslides, or weather events such as tornadoes, hail, and flooding Incidents involving sabotage, severe process upsets from cyber[netic] attack, terrorism, or gunfire

Employers have a "general duty" to protect employees from all of the above hazards, particularly if they had been previously recognized as life-safety hazards [Reference 2]. If a "pro-active" analysis of processes and equipment had been performed, with identification of hazards, the employer must take steps to prevent exposure to the identified hazard or mitigate the likely consequences of the hazard [Reference 9].

\section{Types of Life-Safety Process Hazards Requiring Emergency Escape}

There are many types of materials [and energies] that are used in chemical plants that can cause injuries to employees unless they are carefully controlled and managed. These hazards include the following:

\section{Explosions:}

- Ruptures of equipment from overpressure, as from un-relieved runaway reaction, internal explosion of thermally-unstable material, fire exposure, or other source of internal pressure;

- Ignition of flammable gases, vapors, or dusts, as confined in equipment, rooms, or other enclosures; 
- Initiation of explosives or other unstable materials, from sparks, heat, or impact.

Such incidents may occur without sufficient warning of a need to evacuate the area, and travel distances and travel times are likely to exceed the limits of life-safety codes and standards, because of the explosion-damaged environment. However, the ability of employees to escape from such an environment should be the subject of process-hazard and process-risk assessments, as described later in this presentation.

\section{Fires:}

- Pool fires, from ignition of spilled flammable liquid;

- Flash fires, from ignition of accumulated flammable vapor in process vessels, equipment, in rooms, or other enclosures;

- Jet fires, from ignition of flammable liquid or vapor issuing at high pressure from piping or equipment.

In many of these incidents, there are forewarnings such as flammable gas/vapor alarms, and visual or audible indications of releases. Also, it may be possible to escape from the thermal radiation of fires by moving away from the fire, or by seeking refuge in the "shadow" of walls or equipment, or by moving into a "place of safety".

\section{Toxic-Material Releases:}

- Release of toxic gases or vapors from equipment, storage tanks, or other containers;

- Release and dispersal of toxic dusts from bags, drums, dust collectors, conveyors, or other equipment;

- Release and vaporization of toxic liquids as spills from equipment or storage containers.

- Release of toxic combustion gases and unburned dusts, vapors, and aerosols from explosion vents.

- Release of toxic decomposition or reaction products - including liquids, vapors, and gases - from overpressure-protection relief valves

As with fire hazards, there may be forewarnings such as toxic-gas/vapor alarms, and visual, audible, or odor indications of releases. Also, it may be possible to escape from toxic releases by traveling cross-wind from the release point, or by leaving the enclosed areas in which a release was occurring, or by moving into a "place of safety". 


\section{Stored Energy:}

- Release of potential or kinetic energy from powered equipment that is spring, pneumatic, or hydraulic-powered, and could cause serious and traumatic injury to personnel.

- Exposure to high-voltage and/or high-energy electrical sources that can result in serious or fatal injury.

As with explosions, these hazards may occur without warning. Life-safety codes and standards do not address travel distances and travel times for these types of stored-energy hazards. However, the OSHA standards require ready access to medical assistance.

Thus, life-safety concerns in chemical plants should address escape to a safe location particularly (1) during a fire event or (2) during a toxic-release event, and also (3) following an explosion or energy-release event. These consequences of undesired events should be included as process hazards in evaluations of new or modified processes and in the periodic reevaluations to determine if such hazards are adequately controlled.

This presentation does not directly involve Process Hazards Analyses or Risk Assessments and, instead, focusses on the physical aspects of the plant and its structures. Also, the "post-trauma" care of persons who were injured by the above events - with first-aid or medical treatment - is certainly important but is not within the scope of this presentation.

\section{Guidance Provided by the "Life Safety Code", NFPA 101}

The most-important reference for the protection of employees, contractors, and visitors to a chemical plant is the "Life Safety Code" of the National Fire Protection Association [NFPA], which is published as NFPA 101 [Reference 3]. The pertinent section is Chapter 40, "Industrial Occupancies”, but this Chapter also refers to Chapter 3, "Definitions”; Chapter 4, "General Requirements"; Chapter 6, "Classification of Occupancy and Hazard of Contents”; Chapter 7, "Means of Egress"; and Chapter 8, "Features of Fire Protection".

Although much of the guidance that is presented in NFPA 101 is directed toward protection of personnel from fire, several aspects of this Code would also apply to protection against releases of toxic materials. Less guidance is provided for escape from explosion-damaged structures or from the environment in which equipment has suffered an explosion. No guidance is given in NFPA 101 for escape from an environment where a sudden release of energy had occurred.

\section{Classification of Chemical Plants}

\section{High-Hazard Occupancies}

Almost all chemical plants would be considered to be "High Hazard" occupancies because of the presence of hazards like those that are described above. In the "Life Safety Code, highhazard industrial occupancies include industrial occupancies that use high-hazard materials or 
processes or house high-hazard contents [Reference 10].

The high-hazard materials would include:

- Gasoline and other flammable liquids where possible release of flammable vapors could occur;

- Grain dust, wood flour or plastic dust, aluminum or magnesium dust, or other explosible dusts;

- Explosives storage and handling;

- Combustible flyings or fibrous materials.

There is a limited exception that might apply to some locations in a chemical plant. A "specialpurpose" industrial occupancy would be an area having a low density of personnel and with much of the area occupied by machinery or equipment. The scope of this paper does not include "special-purpose" occupancies except where there is only one exit from that area.

"Ordinary-Hazard Occupancies" represent the conditions found in most buildings and is the basis for the general requirements of the Life Safety Code, where there would be no unduly dangerous exposure to toxic fire gases during the period necessary to escape from a fire area, assuming there are proper exits [Reference 11].

The "Life Safety Code" does not provide a definition of "Low-Hazard Occupancy", except as the storage of non-combustible materials, with some combustible materials or hazardous operations during building repair or maintenance [Reference 12].

\section{Guidance Provided by the International Building Code}

As stated in the Intent paragraph of this Code [Reference 13], "The purpose of this code is to establish the minimum requirements to safeguard the public health, safety and general welfare through structural strength, means of egress facilities, ... and safety to life and property from fire and other hazards ... and to provide safety to fire fighters and emergency responders during emergency operations.”

In the International Building Code [IBC], high-hazard occupancies are defined as structures that involve materials that constitute a physical or health hazard in quantities that exceed the "Maximum Allowable Quantity per Control Area" [Reference 14]. A Control Area is defined as a space that is enclosed by wall, fire barriers, and roofs where hazardous materials are stored, dispensed, used, or handled. Tables are provided in the IBC for a wide variety of materials with physical [fire and explosion] hazards or health [toxicity] hazards, with limits for storage and for use in closed or open systems. The following Table 1 presents examples of the Maximum Allowable Quantities [Reference 15]: 
Table 1

Maximum Allowable Quantities Per Control Area

\begin{tabular}{|c|c|c|c|}
\hline \multicolumn{5}{c}{ PHYSICAL HAZARD } \\
\hline MATERIAL & $\begin{array}{c}\text { CLOSED } \\
\text { SYSTEM }\end{array}$ & $\begin{array}{c}\text { OPEN } \\
\text { SYSTEM }\end{array}$ & $\begin{array}{c}\text { GROUP IF } \\
\text { EXCEEDED }\end{array}$ \\
\hline Combustible Dust & Special Report & Special Report & $\mathrm{H}-2$ \\
\hline Class IA Liquid & 30 gallons & 10 gallons & $\mathrm{H} 2$ or H-3 \\
\hline Class IB or IC Liquid & 120 gallons & 30 gallons & $\mathrm{H}-2$ or H-3 \\
\hline Class II Liquid & 120 gallons & 30 gallons & $\mathrm{H}-2$ or H-3 \\
\hline Class IIIA Liquid & 330 gallons & 80 gallons & $\mathrm{H}-2$ or $\mathrm{H}-3$ \\
\hline Class IIIB Liquid & 13,200 gallons & 3,300 gallons & Not H \\
\hline Flammable Gas & 1,000 std. cu. ft. & Not Applicable & $\mathrm{H}-2$ \\
\hline Liquefied Flamm. Gas & 150 gallons & Not Applicable & $\mathrm{H}-2$ \\
\hline
\end{tabular}

\begin{tabular}{|c|c|c|c|}
\hline \multicolumn{5}{|c|}{ HEALTH HAZARD } \\
\hline Corrosive Liquid & 150 gallons & 100 gallons & $\mathrm{H}-4$ \\
\hline Corrosive Gas & 810 std. cu. ft. & Not Applicable & $\mathrm{H}-4$ \\
\hline Toxic Liquid & 150 gallons & 125 gallons & $\mathrm{H}-4$ \\
\hline Toxic Gas & 801 std. cu. ft. & Not Applicable & $\mathrm{H}-4$ \\
\hline Highly-Toxic Liquid & 4 gallons & 3 gallons & $\mathrm{H}-4$ \\
\hline Highly-Toxic Gas & 20 std. cu. ft. & Not Applicable & H-4 \\
\hline
\end{tabular}

There are several additional types of Physical Hazard materials, and the above quantities can be doubled if used in sprinkler-protected structures or if - for example - contained in approved cabinets, exhaust-ventilated enclosures, or safety cans. Thus, the IBC should be consulted to determine the allowable quantities per control area and the appropriate Group classification if the maximum quantity were to be exceeded.

Ordinary or Moderate-Hazard Occupancies would be "Factory Industrial F-1 Moderate Hazard Occupancy" [Reference 16]. This classification would include all types of occupancies that are not "Low-Hazard Occupancies" nor "High-Hazard Occupancies". The examples that are cited in the IBC include the following manufacturing operations which might be considered to be chemical facilities:

- $\quad$ Beverages, over 12-percent alcohol

- Disinfectants

- $\quad$ Food processing

- $\quad$ Paper mills and products

- $\quad$ Plastic products

- $\quad$ Soaps and detergents

- Wood distillation

Other chemical plants that would be classified as ordinary-hazard or moderate-hazard occupancies would involve "processing, assembly, mixing, packaging, finishing, decorating, or 
repair” [Reference 17]. This definition would include the use of ordinary combustible materials such as finished plastics items, liquids that are non-combustible or have high flash points, powders that are non-combustible or have very large particle sizes, and packaging materials. This definition would exclude processes that involve exothermic reactions, flammable and unstable chemicals, combustible powders and dusts, and other "high-hazard contents", including the handling and storage of such materials.

"Low-Hazard Occupancy" is defined in the International Building Code as "F-2 Factory Industrial" and involves "the fabrication or manufacturing of noncombustible materials which, during finishing, packing, or processing, do not involve a significant fire hazard” [Reference 18]. The examples that are cited include non-alcoholic beverages, brick and masonry manufacture, ceramic products, foundries, and fabrication and assembly of metal products.

\section{High-Hazard Contents}

High-hazard occupancies also would include structures in which "High-Hazard Contents" are handled. The definitions of "High-Hazard Contents” in the NFPA “Life Safety Code” would include the following [Reference 19]:

- Materials that are likely to burn with extreme rapidity or from which explosions are likely, including flammable liquids; combustible agricultural, plastic, metal, and other explosible dusts; and other products of manufacture [Reference 20].

- Materials that generate dangerous smoke or gases, potentially endangering the lives and safety of the occupants of the building or structure [Reference 21].

- Other materials that are classified by the "registered design professional" as being hazardous, based on the character of the material and the processes or operations that are conducted in the building or structure [Reference 22].

Chapters 40 and 42 in the "Life Safety Code” [References 23 and 24] include detailed information concerning the construction of exit passageways, suitable types of protection from hazards, appropriate fire-alarm systems, permitted utility systems, and allowable travel distances.

\section{Emergency-Escape Travel-Distance Requirements}

The NFPA “Life Safety Code” provides the following maximum travel-distance limits for Industrial Occupancies [Reference 25]: 
Table 2

Maximum Travel Distances, NFPA 101

\begin{tabular}{|c|c|c|}
\hline HAZARDS OCCUPANCY & SPRINKLERS & $\begin{array}{c}\text { TRAVEL } \\
\text { DISTANCE }\end{array}$ \\
\hline Special Purpose, Low/Ordinary [Fire] Hazard & Yes & 400 feet \\
\hline Special Purpose, Low/Ordinary [Fire] Hazard & No & 300 feet \\
\hline General Industrial, Low/Ordinary [Fire] Hazard & Yes & 250 feet \\
\hline General Industrial, Low/Ordinary [Fire] Hazard & No & 200 feet \\
\hline High [Explosion] Hazard & Yes & 75 feet \\
\hline High [Explosion] Hazard & No & [Not Permitted] \\
\hline
\end{tabular}

As indicated in the preceding Table, automatic sprinkler protection is required in structures where high-hazard operations are conducted. In any process-hazards or due-diligence audits, the first focus of a walk-through should be on sprinkler protection and the adequacy of a water supplies.

The International Building Code contains similar maximum travel-distance requirements [Reference 26]:

Table 3

Maximum Travel Distances, IBC

\begin{tabular}{|c|c|c|}
\hline HAZARDS OCCUPANCY & SPRINKLERS & $\begin{array}{c}\text { TRAVEL } \\
\text { DISTANCE }\end{array}$ \\
\hline Low [Fire] Hazard, F-2 & Yes & 400 feet \\
\hline Low [Fire] Hazard, F-2 & No & 300 feet \\
\hline Moderate [Fire] Hazard, F-1 & Yes & 250 feet \\
\hline Moderate [Fire] Hazard, F-1 & No & 200 feet \\
\hline High [Toxic] Hazard, H-4 & Yes & 175 feet \\
\hline High [Toxic] Hazard, H-4 & No & [Not Permitted] \\
\hline High [Fire] Hazard, H-3 & Yes & 150 feet \\
\hline High [Fire] Hazard, H-3 & No & [Not Permitted] \\
\hline High [Explosion] Hazard, H-2 & Yes & 100 feet \\
\hline High [Explosion] Hazard, H-2 & No & [Not Permitted] \\
\hline
\end{tabular}

\section{Other Aspects of Emergency-Egress Travel Pathways}

There are many locations in typical chemical plants where there is only one path for access and exit. This might include the following:

- The upper and/or top levels of open structures;

- Platforms on fractionating and extraction columns, strippers, tall reactors, and similar towers, and the ladders or stairways providing access to such platforms;

- Stairs, ladders, or walkways giving access to bucket elevators, belt conveyors, and other material-conveying systems;

- Walkways along pipe racks; 
- Platforms at tank-truck and rail-car loading and unloading locations;

- The top floors, lofts, penthouses, or attics of closed structures,

The NFPA "Life Safety Code" provides the following restrictions on the occupancies of singleexit locations [Reference 27]:

Table 4

Single-Exit Restrictions, NFPA 101

\begin{tabular}{|c|c|c|c|}
\hline HAZARDS OCCUPANCY & SPRINKLERS & $\begin{array}{c}\text { MAX. NO. } \\
\text { OF } \\
\text { PERSONS }\end{array}$ & $\begin{array}{c}\text { TRAVEL } \\
\text { DISTANCE TO } \\
\text { EXIT }\end{array}$ \\
\hline $\begin{array}{c}\text { General Industrial, } \\
\text { Low/Ordinary [Fire] Hazard }\end{array}$ & Yes & $\begin{array}{c}100 \\
\text { sq.ft./person }\end{array}$ & 100 feet \\
\hline $\begin{array}{c}\text { General Industrial, } \\
\text { Low/Ordinary [Fire] Hazard }\end{array}$ & No & $\begin{array}{c}50 \\
\text { sq.ft./person }\end{array}$ & 50 feet \\
\hline High [Explosion] Hazard & Yes & 3 [<200 sq.ft.] & 25 feet \\
\hline High [Explosion] Hazard & No & 3 [<200 sq.ft.] & 25 feet \\
\hline
\end{tabular}

Similarly, the International Building Code has the following limits on the occupancies of singleexit locations [Reference 28]:

Table 5

Single-Exit Restrictions, IBC

\begin{tabular}{|c|c|c|}
\hline HAZARDS OCCUPANCY & $\begin{array}{c}\text { MAX. NO. OF } \\
\text { PERSONS }\end{array}$ & $\begin{array}{c}\text { TRAVEL } \\
\text { DISTANCE TO EXIT }\end{array}$ \\
\hline Low [Fire] Hazard, F-2 & 49 & 75 feet \\
\hline Moderate [Fire] Hazard, F-1 & 49 & 75 feet \\
\hline High [Toxic] Hazard, H-4 & 10 & feet \\
\hline High [Fire] Hazard, H-3 & 3 & 25 feet \\
\hline High [Explosion] Hazard, H-2 & 3 & feet \\
\hline
\end{tabular}

Process-safety audits should examine and evaluate the life-safety aspects of these locations, to determine if persons at these locations could be exposed to fire, explosion, or toxic-material release at lower levels. In particular, the evaluation should determine the protection that should be worn, be carried, or be available at these "dead end" locations. The minimum protection would be an escape respirator, with sufficient capacity to reach safety at ground level. In some locations, it also would be advisable to require the wearing of flame-resistant clothing, if exposure to fire could occur. Further, for some locations, access to "dead-end" areas should be limited to shutdown periods, where there would be no pressurized flammable and/or toxic liquids and gases that could hinder escape.

Process-safety audits also should examine the escape routes from the most-remote points on a floor or platform. The route should be over solid flooring - rather than open grating - for some protection against fire at lower levels [Reference 29]. Measurement of the travel distances from the remote points - from drawings or by physical measurement - should be compared with the maximum travel distances, as described above. 
A likely and frequent consequence of explosion is power failure, with loss of lighting. A lifesafety audit should include a study of emergency lighting of exit pathways around process equipment, and not be limited to stairways, aisles, and corridors.

\section{$\underline{\text { Interior Stairways }}$}

During process-safety studies or audits, the suitability of interior stairways as accesses to exits should be assessed. Unless an interior stairway is well-isolated from hazardous processes, it should not be considered to be useful as an exit pathway [Reference 30].

\section{Toxicity Hazards}

For the life safety of employees, contractors, and visitors - and particularly for the life safety of spill-response teams - the "worst-case" equilibrium concentration above a spill should be determined [Reference 31]. This evaluation should be done for every toxic liquid that is handled in "significant" quantity at a site.

Many toxic liquids and toxic gases have lethal concentrations that typically are characterized by $\mathrm{LC}_{50}$ values; that is, the concentrations that would cause fatality to half of the exposed animals or individuals, usually for a specified duration of exposure. Four hours of exposure to the toxic fluid [gas or vapor] is typical, but shorter or longer durations are quoted in the references [References 32 and 33]. For many fluids and for short exposures - usually less than one hour the product of concentration and duration represents a "dose". This is described by the Haber equation: $\mathrm{D}=\mathrm{Ct}$ ppm-minutes [Reference 34]. For longer exposures, the Haber equation is modified to: $\mathrm{C}^{\mathrm{n}} \mathrm{t}=\mathrm{K}$.

A simple relationship between equilibrium concentration and temperature is the Antoine equation, with conversion to parts per million by volume [ppm]:

$$
\mathrm{C}=(1,000,000)\left(10^{\mathrm{A}-[\mathrm{B} /(\mathrm{T}+\mathrm{C})]}\right) / 760 \mathrm{ppm} \text {. }
$$

Values of the Antoine constants can be found in the literature [Reference 35].

Wearing inadequate breathing protection in a contaminated atmosphere can be life-threatening. To aid in minimizing this hazard, OSHA has issued a table of Assigned Protection Factors:

Table 6

Assigned Protection Factors

\begin{tabular}{|l|c|}
\hline \multicolumn{1}{|c|}{ BREATHING PROTECTION } & APF \\
\hline Air-Purifying [Cartridge] Respirator [APR], \\
Demand Mode; Quarter Mask [Nose and Mouth] & 5 \\
\hline $\begin{array}{l}\text { Air-Purifying [Cartridge] Respirator [APR], } \\
\text { Demand Mode; Half Mask [Nose, Mouth, and Chin] }\end{array}$ & 10 \\
\hline $\begin{array}{l}\text { Air-Purifying [Cartridge] Respirator [APR], } \\
\text { Demand Mode; Full Facepiece }\end{array}$ & 50 \\
\hline
\end{tabular}




\begin{tabular}{|l|c|}
\hline $\begin{array}{l}\text { Supplied-Air Respirator [SAR] or SCBA, } \\
\text { Demand Mode; Half Mask [Nose, Mouth, and Chin] }\end{array}$ & 10 \\
\hline $\begin{array}{l}\text { Supplied-Air Respirator [SAR] or SCBA, } \\
\text { Demand Mode; Full Facepiece or Helmet/Hood }\end{array}$ & 50 \\
\hline $\begin{array}{l}\text { Powered Air-Purifying Respirator [PAPR], } \\
\text { Positive-Pressure; Half Mask [Nose, Mouth, and Chin] }\end{array}$ & 50 \\
\hline $\begin{array}{l}\text { Powered Air-Purifying Respirator [PAPR], } \\
\text { Positive-Pressure; Full Facepiece }\end{array}$ & 1,000 \\
\hline $\begin{array}{l}\text { Powered Air-Purifying Respirator [PAPR], } \\
\text { Positive-Pressure; Helmet or Hood [if tested] }\end{array}$ & 1,000 \\
\hline $\begin{array}{l}\text { Supplied-Air [Airline] Respirator [SAR], } \\
\text { Positive-Pressure; Half Mask [Nose, Mouth, and Chin] }\end{array}$ & 50 \\
\hline $\begin{array}{l}\text { Supplied-Air [Airline] Respirator [SAR], } \\
\text { Positive-Pressure; Full Facepiece }\end{array}$ & 1,000 \\
\hline $\begin{array}{l}\text { Self-Contained Breathing Apparatus [SCBA], } \\
\text { Positive-Pressure; Full Facepiece }\end{array}$ & 10,000 \\
\hline $\begin{array}{l}\text { Self-Contained Breathing Apparatus [SCBA], } \\
\text { Positive-Pressure; Helmet or Hood }\end{array}$ & 10,000 \\
\hline
\end{tabular}

As indicated in this table, high Assigned Protection Factors can only be achieved with full-face positive-pressure protection.

\section{Fire and Explosion Control}

The primary objective of fire and explosion control is to protect life and property by ensuring that concentrations of flammable gases and vapors do not exceed the Lower Flammable Limit [LFL] - or the equivalent Lower Explosive Limit [LEL] - and that concentrations of combustible dusts do not exceed the Minimum Explosible Concentration [MEC].

\section{Flammable Liquids and Gases}

The LFL values for flammable gases and vapor vary from about 0.3 percent by volume - for high-molecular-weight gases and vapors - to about 2.5 percent by volume, or about a factor of eight. However, on a weight-concentration basis, the range is much narrower - from about 26 to 76 grams per cubic meter, or a factor of about three, with an average of about 44 grams per cubic meter. Weight concentrations are important when evaluating the combustibility hazards of "hybrid" mixtures of flammable gases or vapors with combustible dusts [Reference 36].

Life safety from flash fire and explosion involving flammable gases and vapors can be minimized if sufficient ventilation is provided in enclosed spaces to prevent the accumulation of gases and vapors above the LFL. The vapors for most flammable liquids are much denser than air, so floor-level exhaust ventilation should be provided. This is in contrast to window or wall fans that are installed well above floor level. The recommended exhaust-ventilation rate is quite modest, at 1 standard cubic foot per minute per square foot of floor area [Reference 37]. This corresponds to an average velocity along the floor of about 1 foot per minute, or about 0.01 mile per hour. For lighter-than-air gases and hot vapors, a similar exhaust-ventilation rate should be 
provided across the ceiling, again to prevent accumulation of hazardous amounts of flammable and explosible gases [or light vapors].

Spills and unintended releases of flammable liquids from sampling points, dispensing stations, and drains can be minimized by providing "dead man" self-closing valves at these locations [Reference 38]. Thus, unexpected flows or spark-ignition of the flowing material would be stopped when the valve handled is released. Similarly, pump transfers of flammable liquids into open containers should be controlled with a "dead man" switch, such that releasing the switch or removing pressure from a pushbutton would stop the flow.

The vapor concentrations above flammable-liquid spills can be greatly reduced by covering the spill with foam [Reference 39] or a non-combustible granular material, such as vermiculite, amorphous mineral silicates [such as “Sorb-All”], and “kitty litters” based on baking soda. Thus, the first action of an emergency response team would be to cover the spill to reduce the likelihood of ignition of the vapors.

\section{Combustible Dusts [and Aerosols and Mists]}

The MEC values for combustible dusts [and aerosols and mists] range from about 15 grams per cubic meter to about 60 grams per cubic meter. Thus, on a weight-concentration basis, the lower combustion limits for gases, vapors, aerosols, mists, and dusts [Reference 40] are quite similar.

For combustible dusts, floor-level exhaust ventilation is not very effective in preventing the accumulation of dusts, since the densities of dust particles typically are three orders of magnitude greater than the density of air. Thus, local exhaust ventilation should be provided to minimize the size and density of dust clouds at locations where such clouds could exist [Reference 41]. This would include powder-bagging stations, powder-recovery operations, dust removal from dust collectors, ductwork cleaning, and similar activities where dense clouds of dust could occur. For guidance concerning the dust-combustion hazard, the "rule of thumb" is pertinent: if the thumb can be seen at the end of the outstretched arm, the dust-cloud density is likely to be too low to allow propagation of combustion [Reference 42]. Conversely, extremely-poor visibility is an indication of a dust-explosion hazard.

Accumulations of combustible dusts should be prevented, particularly on elevated surfaces, to minimize the likelihood of flash fires and primary and secondary explosions [Reference 43]. The elevated surfaces would include roof-support structures, ductwork, piping, light fixtures, and process equipment. Guidance that is provided in the NFPA publications includes the following [References 44 and 45]:

Table 7

Housekeeping Guidelines

\begin{tabular}{|c|c|c|}
\hline Dust-Layer Depth & Frequency & Housekeeping \\
\hline $\begin{array}{c}\text { Less than } 1 \mathrm{~mm} \\
{[<1 / 32 ”]}\end{array}$ & Infrequent & $\begin{array}{c}\text { Clean to maintain }<1 \mathrm{~mm} \text { and to } \\
\text { ensure surface colors are discernible }\end{array}$ \\
\hline 1/32” to 1/8” & Infrequent & Clean up during the same shift \\
\hline More than 1/8” & Two or three times per year & Immediately shut down and clean \\
\hline
\end{tabular}


The above guidance is primarily for electrically-unclassified areas. If the area is classified Class II, Division 1 or Division 2, then greater cleaning intervals would be permissible.

It is also important that the concentration of combustible dusts be kept below the MEC in process equipment, unless the concentration of oxygen is reduced by inerting [with nitrogen, for example; Reference 46]. If high velocities are maintained in exhaust-ventilation systems above 4,000 feet per minute [20 meters per second], for example [Reference 47] - this usually would be sufficient to prevent accumulations of dust in ductwork and also to maintain low suspended-dust concentrations.

\section{Emergency-Response Teams}

Members of a site's Emergency-Response Team [ER Team] are the employees that are mostlikely to be exposed to toxic materials, in providing life-safety for other employees, contractors, and visitors. Although the frequency of such exposures might be very low, the ER Team must be well-prepared for almost every eventuality.

The minimum protection for the life safety of members of the ER Team would be the following:

- Body protection - flame-resistant and full-coverage outer clothing, for protection against flash fire and sprays of liquid.

- $\quad$ Eye protection - goggles and/or face shield, for protection against liquid sprays, flash fire, and hazards during access to - or escape from - damaged structures.

- $\quad$ Head protection - hard hat or helmet, for protection from head-bumping hazards and falling debris.

- $\quad$ Hand protection - heat-resistant gloves, with long cuffs

- $\quad$ Foot protection - hard-toe, steel-footplate, and slip-resistant safety shoes or boots, for protection against spilled liquids and dusts and against penetrating objects in access and exit pathways.

- $\quad$ Breathing protection - for protection against combustion gases, toxic gases and vapors, and toxic or nuisance dusts.

The equipment that should be provided for the ER Team would include some or all of the following:

- $\quad$ Fire extinguishers: A [ordinary combustibles], B [flammable liquids], C [non-conductive], and D [metals].

- $\quad$ Spill-control equipment: spill-covering non-combustible granules ["Spill-X” extinguisher-type applicators; absorbent "pigs"; etc.]

- $\quad$ Drain covers

- $\quad$ Rescue equipment: ropes, stretchers, spineboard, gurneys, hoists.

- $\quad$ Site maps, showing stairways, elevators, safety showers, wheeled extinguishers.

- Water hoses

- $\quad$ Portable battery-operated lights, flash lights

- $\quad$ Defibrillator, oxygen supply and mask 


\section{- $\quad$ First-aid kit, splints, blankets}

- $\quad$ A cart or vehicle-pulled wagon to contain the spill-control and rescue equipment, and the personal protective equipment for the ER Team members.

Special training for the members of the ER Team would be needed, to recognize hazards to their own life safety, including entry into confined spaces, exposure to high voltages, and exposure to toxic and flammable gases, vapors, and dusts. Members of the ER Team must also be able to recognize when a situation is "beyond control" and when it is essential for them to escape from the uncontrollable hazards.

\section{Formal Analysis of Operations for Life-Safety Hazards}

\section{Process Hazards Analysis, or Risk Analysis}

There are several methods that are in current use for analysis of processes for hazards, and the "most popular" is the Hazard and Operability [HAZOP] method. Whichever method is used, it is important that the analysis not be limited to a "conference-room" or "ivory-tower" study of Piping and Instrument Diagrams [P\&IDs] or a review of Standard Operating Procedures [SOPs]. It certainly is important to ensure that control systems are designed to contend with process upsets [through a P\&ID study], and that operators are properly trained in process control [through review of SOPs. However, these studies should be accompanied by first-hand study of the following:

- $\quad$ Evaluate the life-safety of operators, mechanics, contractors, and visitors in operating areas, to ensure that they have ready access to exits.

- $\quad$ Study the process equipment to ensure that overpressure protection has been properly installed, as shown in P\&IDs, to prevent rupture.

- $\quad$ Discuss the Operating Procedures with operating personnel, supervisors, and process engineers, to determine if they all are comfortable with the process and the procedures that they are required to follow.

The OSHA “Process Safety Management” standard requires Material Balances and Energy Balances - which are easily and rather-accurately calculable. However, it is perhaps more important that a "Power Balance" be developed, to show how the power [joules per second, or watts per milliliter [Reference 48] for an exothermic reaction is controlled, or how the power delivered to an endothermic reaction is adequately controlled. The power developed by an exothermic reaction cannot be calculated and must be determined by test, using equipment such as the "RC1" which allows confident scale-up.

Assistance by a "third-party" process-safety specialist often can provide a "fresh set of eyes", when identifying [and adequately controlling] unrecognized hazards is important. 


\section{Job Safety Analysis}

There are many operations - in addition to the operation of chemical processes - where there are life-safety hazards. They include process-vessel entry [confined-space entry], processequipment lockout [such as valves at pumps], removal of combustible dust from ductwork, cleanup of flammable-liquid spillage, truck loading and unloading, flexible-hose transfers of toxic liquids and gases, lift-truck operations, and shrink-wrapping. The purpose of Job Safety Analysis is to ascertain whether or not the procedures are sufficient to provide life-safety and to see if the practices match the procedures. When the practices do not match the procedures, this indicates that the site's Management of Change procedure is ineffective and needs attention, in application and authorizations.

\section{“Near-Miss” Reporting}

"Near-Misses" sometimes are events that could have been hazardous to health or life, except that one or more Layers of Protection functioned properly to prevent escalation of the event. Reporting of such "Near-Misses" is important - as "lessons to be learned" - to ensure that appropriate engineering or administrative controls are put in place to prevent recurrence. Thus, reporting of "Near-Misses" should be encouraged, even to the point of encouraging anonymous reporting of such events. Further, investigation of "Near-Misses" is as important as investigation of process incidents, particularly if a hazard to life might be involved.

\section{$\underline{\text { Leading Indicators }}$}

In a manner similar to the treatment of "Near-Misses", a site should establish appropriate leading indicators, to aid in determining how possibly-limited resources should be allocated. Of several types of leading indicators, perhaps the most-important is "trends" in safety performance. This would include the frequency of serious injuries - particularly process-related injuries - and the frequency of serious process upsets. The latter would include the frequency of releases from relief valves and explosion vents, frequency of interlock or manual emergency shutdowns of processes, frequency of spills of flammable liquids or releases of combustible dusts, and the frequency of "Near-Misses".

\section{Conclusion}

Chemical plants can have a wide variety of life-safety hazards. Pertinent Codes and Standards provide good guidance concerning the avoidance and mitigation of such hazards. A comprehensive Process Hazards Analysis or Risk Assessment can aid in identifying hazards, and members of the PHA or RA Team should be expected to propose improvements to minimize the life-safety hazards. The PHA or RA should include a thorough field study of the process equipment and, particularly, how employees, contractors, and visitors would escape to a safe location if a fire, explosion, or toxic release were to occur.

There are several types of life-hazard warnings that should be reported, investigated, and corrected, including "Near-Misses" and trends in safety performance. With well-directed efforts to identify and correct life-safety hazards, the "General Duty” responsibility for 
providing a "safe place to work" would be accomplished.

\section{References}

1. U. S. Department of Labor, "Occupational Safety and Health Act of 1970" (December 29, 1970); www.dol.gov/dol/aboutdol/history/osha.htm.

2. U. S. Department of Labor, “Occupational Safety and Health Act of 1970”, Section 5, "Duties" (December 29, 1970).

3. National Fire Protection Association, "Life Safety Code", NFPA 101 (2015).

4. U. S. Department of Labor, Occupational Safety and Health Administration, "Occupational Safety and Health Standards", Title 29 of the Code of Federal Regulations, Paragraph 1910.34(b).

5. U. S. Department of Labor, Occupational Safety and Health Administration, "Occupational Safety and Health Standards", Title 29 of the Code of Federal Regulations, Paragraph 1910.37(a).

6. U. S. Department of Labor, Occupational Safety and Health Administration, "Occupational Safety and Health Standards", Title 29 of the Code of Federal Regulations, Paragraph 1910.35.

7. International Code Council, "International Fire Code” (2012).

8. Center for Chemical Process Safety [AIChE], "Guidelines for Risk-Based Process Safety”, Page 215 (2007).

9. Center for Chemical Process Safety [AIChE], "Guidelines for Risk-Based Process Safety”, Page 220 (2007).

10. National Fire Protection Association, "Life Safety Code”, NFPA 101, Paragraphs 40.1.2.1.3, 3.3.190.8.2, and A.3.3.190.8.2 (2015).

11. National Fire Protection Association, "Life Safety Code", NFPA 101, Paragraph A.6.2.2.3 (2015).

12. National Fire Protection Association, "Life Safety Code”, NFPA 101, Paragraph A.6.2.2.2 (2015).

13. International Code Council, "International Building Code”, Paragraph 101.3 (2012).

14. International Code Council, "International Building Code”, Paragraph 307.1 (2012).

15. International Code Council, "International Building Code”, Tables 307.1(1) and 307.1(2) (2012).

16. International Code Council, "International Building Code”, Paragraph 306.2 (2012).

17. National Fire Protection Association, "Life Safety Code”, NFPA 101, Paragraph A.7.6.1 (2015).

18. International Code Council, “International Building Code”, Paragraph 306.3 (2012).

19. National Fire Protection Association, "Life Safety Code", NFPA 101, Paragraphs 6.2.2.4 and A.6.2.2.4 (2015).

20. National Fire Protection Association, “Life Safety Code”, NFPA 101, Paragraph 6.2.1.1 (2015).

21. National Fire Protection Association, "Life Safety Code”, NFPA 101, Paragraph 6.2.1.2 (2015).

22. National Fire Protection Association, “Life Safety Code”, NFPA 101, Chapter 40, "Industrial Occupancies" (2015). 
23. National Fire Protection Association, "Life Safety Code”, NFPA 101, Chapter 42, "Storage Occupancies" (2015).

24. National Fire Protection Association, “Life Safety Code”, NFPA 101, Paragraph 40.2.6.1 and Table 40.2.6.1 (2015).

25. International Code Council, “International Building Code”, Paragraph 306.3 (2012).

26. International Code Council, "International Building Code”, Table 1016.2 (2012).

27. National Fire Protection Association, “Life Safety Code”, NFPA 101, Paragraphs 40.2.4.1.2 and 7.11.4 (2015).

28. International Code Council, “International Building Code”, Table 1015.1 (2012).

29. National Fire Protection Association, “Life Safety Code”, NFPA 101, Paragraph 7.2.6.5 (2015).

30. International Code Council, “International Building Code”, Paragraph 1022.2 (2012).

31. National Institute for Occupational Safety and Health, "Registry of Toxic Effects of Chemical Substances” (1983).

32. Prugh, R. W., "Toxicity-Hazard Index and the 'Infinite Point' “, during the $11^{\text {th }}$ Global Congress on Process Safety (April 28, 2015).

33. Lewis, Richard J., Sr., “Sax’s Dangerous Properties of Industrial Materials”, $9^{\text {th }}$ Ed. (1996).

34. Prugh, R. W., “Quantitative Evaluation of Inhalation-Toxicity Hazards”, Paper 5c in the Proceedings of the $29^{\text {th }}$ Annual Loss Prevention Symposium (August 1, 1995).

35. Dean, J. A., “Lange’s Handbook of Chemistry”, $13^{\text {th }}$ Ed., Tables $\underline{10}-7$ and $\underline{10}-8$ (1985).

36. Prugh, R. W., "The Relationship Between Flash Point and Lower Flammable Limit and Application to Hybrid Mixtures”, AIChE 2007 Spring Meeting in Houston, TX on April 22-26, 2007; page 156 in "Process Safety Progress", vol. 27, No. 2 (June 2008).

37. National Fire Protection Association, "Flammable and Combustible Liquids Code”, NFPA 30, Paragraphs 17.11.3 and 18.6.1 (2015).

38. National Fire Protection Association, "Flammable and Combustible Liquids Code”, NFPA 30, Paragraph 18.5.2 (2015).

39. Mannan, S., “Lees' Loss Prevention in the Process Industries”, $3^{\text {rd }}$ Ed., Pages 15/324 and 23/72 (2005).

40. Society for Chemical Engineering and Biotechnology [DECHEMA] and others, "Combustion and Explosion Characteristics of Dusts", GESTIS-DUST-EX, $2^{\text {nd }}$ Ed., (2001).

41. National Fire Protection Association, "Standard for the Prevention of Fire and Dust Explosions from the Manufacturing, Processing, and Handling of Combustible Particulate Solids”, NFPA 654, Paragraphs 7.3.2.6 and A.7.3.2.6.8 (2013).

42. Eckhoff, R. K., "Dust Explosions in the Process Industries”, $2^{\text {nd }}$ Ed., Pages 9, 72, and 73 (1999).

43. National Fire Protection Association, "Standard for the Prevention of Fire and Dust Explosions from the Manufacturing, Processing, and Handling of Combustible Particulate Solids”, NFPA 654, Paragraphs 8.2.1.1 and A.8.2.1.1 (2013).

44. National Fire Protection Association, "Recommended Practice for the Classification of Combustible Dusts and of Hazardous (Classified) Locations for Electrical Installations in Chemical Process Areas”, NFPA 499, Tables A.6.3.2(a) and A.6.7 (2013).

45. National Fire Protection Association, "Standard for the Prevention of Fire and Dust Explosions from the Manufacturing, Processing, and Handling of Combustible 
Particulate Solids”, NFPA 654, Tables A.8.2.1.3(a) and (b) (2013).

46. National Fire Protection Association, "Standard on Explosion Prevention Systems", NFPA 69, Chapter 7 (2014).

47. American Conference of Governmental Industrial Hygienists, "Industrial Ventilation", $25^{\text {th }}$ Ed., Page 7-21 (2004).

48. National Fire Protection Association, "Standard System for the Identification of the Hazards of Materials for Emergency Response”, NFPA 704, Table 7.2 and Annex E (2012). 